\title{
PENGGUNAAN ALAT MUSIK TRADISIONAL SEBAGAI MEDIA PENGEMBANGAN MOTORIK KASAR DAN KOGNITIF ANAK
}

\author{
Karin Ariska ${ }^{1}$, Naimah $^{2}$ \\ Ilmu Tarbiyah dan Keguruan, UIN Sunan Kalijaga ${ }^{1}$ \\ Ilmu Tarbiyah dan Keguruan, UIN Sunan Kalijaga ${ }^{2}$ \\ Email: Karinariska563@gmail.com ${ }^{1}$, drnaimah24@gmail.com ${ }^{2}$ \\ Ariska, Karin., Na'mah. (2020). Penggunaan Alat Musik Tradisional Indonesia Sebagai Media \\ Pengembangan Motorik Kasar dan Kognitif Anak Usia Dini. Jurnal Pelita PAUD, 4(2), 276-286. \\ doi: https://doi.org/10.33222/pelitapaud.v4i1.1011
}

Diterima:20-06-2020

Disetujui: 23-06-2020

Dipublikasikan: 29-06-2020

Abstrak: Kaitan antara musik dan pengembangan kecerdasaan anak usia dini telah lama
menjadi tema penelitian dan diskusi para ahli pendidikan anak usia dini. Aktivitas musik
memberikan berbagai manfaat bagi pengembangan kecerdasaan anak, khususunya
kecerdasan motorik dan kognitif. Berbagai implementasi pembelajaran musik yang
dilakukan oleh peneliti maupun pendidik asing memfokuskan pada penggunaan alat musik
yang berasal dari kebudayaan barat, seperti xylophone, piano, drum, dan lain-lain.
Penelitian ini bertujuan untuk mengembangkan pemanfaatan musik dalam konteks
pendidikan anak usia dini, namun penulis perlu memperlihatkan bahwa berbagai manfaat
dari aktivitas musik dicapai melalui penggunaan alat musik tradisonal Indonesia, seperti
gamolan dan angklung. Penelitian ini menggunakan metode penelitian studi literatur,
artikel ini menelaah penelitian yang tersedia dalam jurnal online sebagai contoh aplikasi
alat musik tradisional Indonesia dalam proses pembelajaran Anak Usia Dini. Penelitian ini
menunjukkan bahwa alat musik tradisional Indonesia seperti gamolan Lampung dan
Angklung Jawa Barat juga dapat menjadi media yang efektif bagi pengembangan
kecerdasan motorik dan kognitif anak usia dini. Kata kunci: Alat musik tradisional Indonesia, pengembangan motorik kasar, pengembangan kognitif anak.

Abstract: The link between music and the development of early childhood intelligence has long been the theme of research and discussion of early childhood education experts. Music activities provide various benefits for the development of children's intelligence, especially motor intelligence and cognitive. Various implementations of music learning conducted by foreign researchers and educators focus on the use of musical instruments originating from western culture, such as xylophone, piano, drums, and others. This study aims to develop music utilization in the context of early childhood education, but the authors need to show that the various benefits of music activities are achieved through the use of traditional Indonesian musical instruments, such as gamolan and angklung. This study uses a literature study research method, this article examines the research available in online journals as an example of the application of traditional Indonesian musical instruments in the Early Childhood learning process. This research shows that traditional Indonesian musical instruments such as the Lampung gamolan and Angklung West Java can also be an effective medium for the development of motor intelligence and cognitive early childhood.

Keywords: Indonesian traditional musical instruments, gross motor development,

(C) 2020 Karin Ariska ${ }^{1}$, Naimah ${ }^{2}$

Under the license CC BY-SA 4.0

http://jurnal.upmk.ac.id/index.php/pelitapaud 


\section{PENDAHULUAN}

Musik dan pengembangan kecerdasaan anak usia dini telah lama menjadi topik penelitian serta bahan diskusi bagi para ahli pendidikan anak usia dini, di antaranya oleh Wisbey (Wisbey, 1980); Artan \& Balat (Artan Ismihan \& Balat, 2003); Miendlarzewska \& Trost (Miendlarzewska \& Trost, W., 2014); Corrigall \& Schellenberg (Corrigall \& Schellenberg, 2015); serta Harrison (Harrison, 2016). Semua ahli tersebut memiliki pendapat yang serupa, bahwasannya musik mampu memberikan berbagai manfaat yang dapat membantu pengembangan kecerdasaan anak, khususnya kecerdasan motorik dan kognitif. Oleh karena itu, musik menjadi kegiatan yang tidak terpisahkan dalam proses kegiatan belajar mengajar anak usia dini, bahkan sebelum ditetapkan dan dinyatakan secara jelas dalam Permendikbud nomor 137 tahun 2014. Bernyanyi, sejak lama merupakan salah satu kegiatan yang sudah lama menjadi strategi bagi guru di kelas dalam menyampaikan materi. Hal ini dikarenakan musik mampu berkontribusi dalam menyampaikan materi belajar mengajar, sehingga murid dapat menerima ataupun menghafal secara lebih mudah. Misalnya menyampaikan pengetahuan nama-nama hari, peserta didik akan lebih mudah mengingatnya lewat lagu (Musfiroh, 2008).

Strategi semacam itu bukan sesuatu yang baru dalam kegiatan belajar mengajar Anak Usia Dini. Bahkan, musik juga mampu menjadi materi pembelajaran itu sendiri, yang mana, musik menjadi materi yang dipelajari oleh para peserta didik. Dengan kata lain, para murid belajar memainkan instrumen musik. Hal ini bertujuan untuk mengembangkan dan meningkatkan kecerdasan musikal para peserta didik.Pengembangan aspek ini berkaitan erat dengan pengembangan kecerdasan lainnya seperti stimulasi visualspasial, musikal, kinestetik, dan naturalistik. Pengembangan kecerdasan musik dapat menjadi sarana bagi pengembangan aspek kecerdasan lainnya seperti kepekaan terhadap alam, kemanusiaan, ketuhanan, perasaan, serta kinestetik (Rasyid, 2016).

Banyak manfaat dari kegiatan bermusik, membuat para pendidik yang berfokus pada Pendidikan anak usia dini menyadari arti penting pembelajaran musik. Baik itu sebagai pengembangan kecerdasan musikal anak maupun sebagai sarana untuk mengembangkan kecerdasan lainnya seperti sosial-emosional, kecerdasan spiritual, kognitif, bahasa maupun kinestetik (Rasyid, 2016). Menurut Lwin kecerdasan musikal adalah kemampuan untuk menyimpan nada dalam benak seseorang, mengingat irama itu, dan secara emosional terpengaruh oleh music (Lwin, 2005). Musik dapat memberikan berbagai manfaat bagi anak-anak. Diantaranya adalah: meningkatkan kreatifitas dan imajinasi, meningkatkan kecerdasan, meningkatkan daya ingat, membantu pengembangan kecerdasan lain serta memberikan terapi pada diri kita (Lwin, 2005).

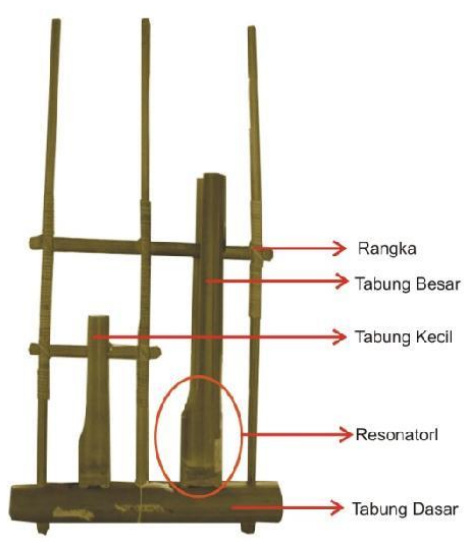

Musik juga dapat menjadi sarana yang baik dalam proses pembelajaran. Colin Rose berpendapat bahwa musik menjadi pendorong dalam proses belajar. Sehingga tidak heran ilmuan seperti Einstein, Plato dan Lazanov mengutamakan musik tertentu sebagai pendorong proses belajar mereka. Studi-studi mutakhir menunjukkan bahwa kegiatan mendengar maupun bermain musik bisa melatih otak untuk menghadapi pembelajaran yang lebih kompleks (Rose, Colin \& Malcolm, J., 2002). Menurut penelitian di Pusat Neurobiologi Pembelajaran dan Memori, Universitas California, mendengarkan musik dapat meningkatkan dan memperbesar kekuatan otak manusia (Rose, Colin \& Malcolm, J., 2002).

Salah satu penelitian yang dilakukan oleh Raucher menunjukkan ada peningkatan IQ spasial para mahasiswa yang didengarkan 
musik dan tidak didengarkan musik. Musik juga dapat menyambungkan jaringan syaraf yang dilihat dari pencitraan resonasi magnetik. Selain itu orang yang bermain alat musik, seperti gitar menunjukkan jumlah korteks yang lebih sebesar dari orang yang tidak memainkan alat musik. Ini disebabkan karena keaktifan jari-jari yang mereka gunakan saat bermain gitar (Rose, Colin \& Malcolm, J., 2002).

Tidak hanya pendidik, besarnya manfaat musik dalam proses perkembangan anak yang sebagaimana dijelaskan sebelumnya juga disadari oleh pihak - pihak yang terkait dengan dunia pendidikan anak. Melalui kementerian pendidikan, musik telah menjadi salah satu Standar Tingkat Pencapaian Pembelajaran Anak Usia Dini. Hal ini sebagaimana tertera dalam Peraturan Mentri Pendidikan dan Kebudayaan Republik Indonesia Nomor 137 tahun 2014.

Ada banyak media yang digunakan oleh Taman Kanak - kanak untuk tujuan semacam ini. Misalnya saja media alat musik yang paling sering digunakan adalah Drum Band. Drum Band banyak digunakan sebagai kegiatan musik di Taman Kanak - Kanak atau Raudhatul Athfal karena sebagian besar alat musik yang digunakan dalam drum band adalah jenis perkusif (alat musik pukul). Sehingga mudah dipelajari dan dimainkan oleh Anak Usia Dini. Hingga hari ini kita dapat melihat banyaknya perlombaanperlombaan maupun festival drumband yang diselenggarakan untuk Anak Usia Dini, termasuk di provinsi Lampung.

Selain menggunakan drumband sebagai media pengembangan musik Anak Usia Dini, tidak sedikit saat ini Taman Kanak - kanak di Indonesia memilih menggunakan alat musik yang berasal dari budaya tradisi masyarakatnya. Di Jawa Tengah dan Jawa Timur misalnya, menggunakan alat musik gamelan (Widintoro, 2020).

Taman Kanak - Kanak di Jawa Barat yang menggunakan angklung (Roska, 2020) Taman Kanak - Kanak di Bali menggunakan Gambang Bambu. Penggunaan alat musik tradisi semacam ini tidak hanya bermanfaat bagi pengembangan kecerdasan anak semata, namun juga mendorong pengenalan kearifan lokal, penguatan identitas budaya bangsa serta memupuk kecintaan terhadap tanah air sejak usia dini (Asolihin, 2020).

Penelitian ini secara khusus bertujuan untuk melihat penggunaan alat musik tradisional Indonesia sebagai media pengembangan kecerdasaan motorik dan kognitif peserta dalam Pendidikan anak usia dini. Alat musik yang dimaksud adalah gamolan yang merupakan alat musik tradisional masyarakat Lampung dan angklung alat musik tradisional masyarakat di Jawa Barat. Penelitian ini hendak memberi manfaat yang dicapai melalui penerapan pembelajaran alat musik gamolan dan angklung.

\section{METODE PENELITIAN}

Penelitian ini merupakan penelitian studi literatur dengan menelaah dua artikel sebagai sample terkait penggunaan alat musik tradisional Indonesia, yakni gamolan Lampung dan Angklung sebagai media pengembangan aspek motorik dan kognitif dalam konteks pendidikan anak usia di dini. Telaah pembelajaran gamolan pada Pendidikan Anak Usia Dini berasal dari penelitian yang dilakukan oleh Karin Ariska berjudul "Penggunaan Gamolan sebagai Pengembangan Aspek Motorik Kasar Anak Usia Dini di Raudhatul Athfal At-Tamam Bandar Lampung antara tahun 2017 - 2018 (Ariska, 2018). Sementara telaah pembelajaran angklung berasal dari penelitian yang dilakukan oleh Dini Nurmalina Firsty dan Myrnawati C.H, Hapidin di tahun 2017 dengan judul "Peningkatan Pemahaman Konsep Bilangan Melalui Bermain Angklung" yang dipublish dalam Jurnal Ilmu Pendidikan Harmonia (Nurmala, 2017).

Menggunakan metode studi pustaka, artikel ini hendak menunjukan bahwa alat musik tradisional Indonesia seperti gamolan Lampung dan Angklung Jawa Barat juga dapat menjadi media yang efektif bagi pengembangan kecerdasan motorik dan kognitif anak usia dini. Hasil dari telaah literatur ini akan digunakan untuk mendukung pemanfaat musik sebagai kegiatan yang efektif bagi pengembangan aspek motorik dan kognitif anak, serta mendukung pemanfaatan alat musik trasidional Indonesia sebagai media untuk mencapai tujuan tersebut. 


\section{HASIL \\ PEMBAHASAN \\ Sekilas Alat musik Tradisional \\ Gamolan dan Angklung}

Gamolan adalah salah satu alat Musik

Tradisional Masyarakat Lampung jenis perkusi, yang dimainkan dengan cara dipukul dengan menggunakan stik (alat pemukul). Dahulunya alat musik ini digunakan sebagai alat komunikasi. Apabila terdengar suara Gamolan, atau ada yang memainkan Gamolan dengan sendirinya masyarakat berkumpul mencari sumber suara Gamolan tersebut (Hasyimkan, 2011).

Gamolan sering juga disebut dengan cetik atau gamolan pekhing. (pekhing berarti bamboo dalam Bahasa Lampung). Gamolan tertua diperkirakan berasal dari Lampung Barat. Dalam buku Musical Instruments of Indonesia, Margaret J. Kartomi menuliskan hasil penelitian yang dilakukannya pada tahun 1983 mengenai tumbuh kembangnya alat musik ini di masyarakat Lampung (Yampolsky, 1996).

Alat musik ini menjadi salah satu sarana hiburan dan berkesenian masyarakat sekitar yang sebagian besarnya hidup di persawahan, lereng gunung, kebun dan semacamnya (Hasyimkan, 2011). Dalam penelitian Yampolsky tentang musik yang ada di Sumatra, dijelaskan bahwa gamolan juga disebut dengan istilah kulitang. Namun Gamelan perunggu atau Talo Balak di daerah Melinting Lampung Timur juga disebut dengan nama Kulintang, sebab bagi mereka Lampung, setiap alat musik yang digunakan untuk memainkan musik Lampung dinamakan Kulintang (Yampolsky, 1996).

Alat musik gamolan terdiri dari beberapa bagian, yaitu bilah dan bagian baluk, tali nilon, ganjal, juga ada alat untuk memukul yang terbuat dari bahan . Berikut bagianbagian pada alat musik gamolan :

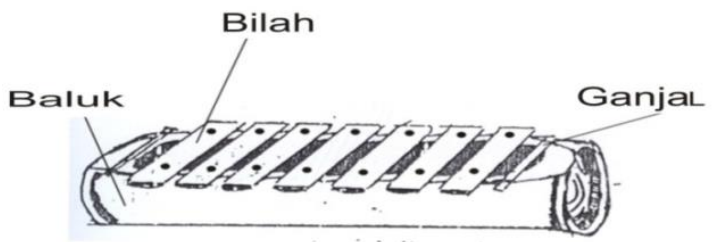

Gambar 1 : sketsa bagian-bagian alat musik gamolan
Bilah

Bilah adalah bagian dari alat musik yang dapat mengeluarkan bunyi nada yang berbeda-beda ketika dipukul. Bilah gamolan terdiri dari 7 bilah yaitu nada do, re, mi, sol, la, si dan do (1 233567 i). Ada juga yang berjumlah 8 bilah yaitu nada (1 235567 i 2), Namun yang banyak digunakan saat ini hanya 7 bilah saja yaitu nada (1 233567 i). Jenis panjang dan pendek pada bilah ada dua macam. Bilah yang terdapat pada melodi gamolan ini terbuat terbuat dari pekhing balak, sementara baluk pada gamolan terbuat dari petung.

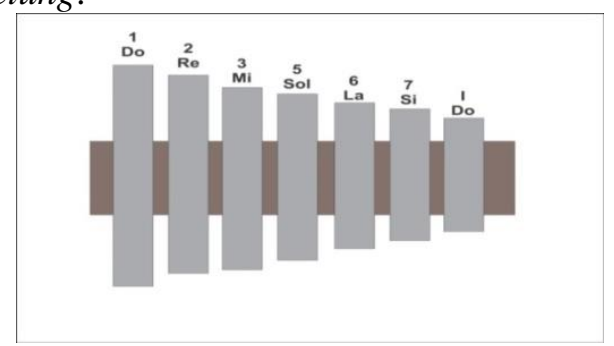

Gambar 2: Sketsa Bilah Gamolan bilah 7

\section{a) Ganjal}

Ganjal digunakan untuk menahan senar pada baluk. Ganjal yang dimaksudkan terbuat dari yang ukuran besarnya sama dengan alat pemukul gamolan, hanya saja panjang ukurannya disesuaikan dengan panjang bilah. Bilah bagian sebelah kiri yang bernada rendah lebih panjang dari bilah yang sebelah kanan yang bernada lebih tinggi, yang tentunya ganjal sebelah kiri juga lebih panjang dari yang sebelah kanan. Fungsi ganjal ini untuk menahan tali nilon yang dipasang di baluk atau dudukan gamolan.

\section{b) Baluk}

Baluk adalah tempat dudukan bilah. Untuk baluk atau dudukan bilah dipilih betung yang utuh berdiameter kurang lebih $12 \mathrm{~cm}$, kemudian diberi lubang antara 7-10 $\mathrm{cm}$ dan panjangnya $45 \mathrm{~cm}$. pada awalnya baluk yang bagian bawah diratakan agar gamolan ini jika diletakkan tidak miring, lalu perkembangan kemudian diberi alas yang terbuat dari juga yang dipaku secara melintang di bagian bawah baluk di sisi kanan dan kiri. baluk juga dilubangi di bagian kiri dan kanan, lubang disesuaikan dengan ukuran besar tali nilon untuk pancing no 300, tapi pada zaman dulu tali tersebut terbuat dari rotan. Tali nilon 
pancing tersebut untuk mengikatkan bilahbilah yang diganjal juga dengan yang dibuat sebesar-besar lidi yang ukuran panjangnya kira-kira $2 \mathrm{~cm}$, kemudian tali nilon tersebut terhubungkan ke baluk (Hasyimkan, 2011).

\section{Pemukul}

Pemukul (stick) adalah sepasang alat pemukul yang terbuat dari bahan baku yang berfungsi untuk memukul bilah-bilah. Panjang ukuran dari pemukul kurang lebih $20 \mathrm{~cm}$, dan

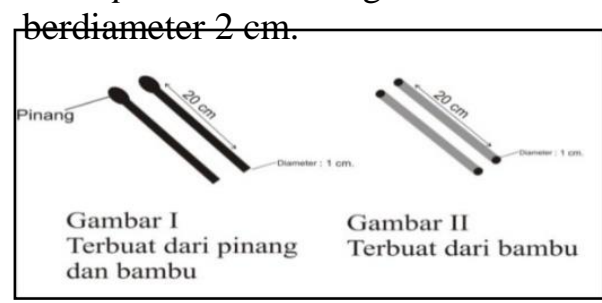

Gambar 3. gambar 1 Model pemukul menggunakan buah pinang pada ujungnya, gambar 2 model pemukulyang baru hanya menggunakan

Pada awalnya digunakan pemukul pada gambar 1 yang terbuat dari buah pinang pada salah satu ujungnya, namun saat ini digunakan pemukul pada gambar 2, yang seluruhnya terbuat dari bahan baku.

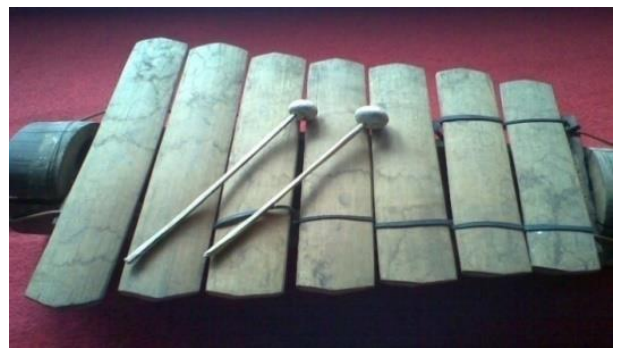

Gambar 4: Pemukul gamolan menggunakan buah pinang pada ujungnya.

Angklung berdasarkan etimologi berasal dari dua kata, yakni "angk" yang berarti suara/ nada dan "klung" yang berarti patah atau hilang. Menurut Soepriadi, hal tersebut dapat diartikan, "nada-nada selendro yang tidak lengkap, karena angklung hanya menggunakan 4 nada dari rentang nada selendro. Dalam tangga nada selendro ada lima nada, $1=$ da, $2=\mathrm{mi}, 3=\mathrm{mi}, 4=\mathrm{na}$, ti=la, $5=$ da. Sementara dalam angklung hanya terdiri dari empat nada, yaitu la, da, mi, ti (Supriadi, 2006). Namun saat ini angklung mengalami perkembangan, telah banyak angklung yang menggunakan sistem tangga nada barat (diatonic) yang terdiri dari nadanada, do, re, mi, fa, sol, la, si, do.

Terdapat berbagai jenis angklung yang berkembang di wilayah Jawa Barat bertangga nada/ berlaras Sunda seperti salendro, pelog/degung. Namun ada pula angklung yang bertangga nada diatonis seperti yang dikembangkan oleh Daeng Soetigna seorang tokoh budaya Indonesia/Nusantara berasal dari Sunda (Jawa Barat) yang berinsiatif mengubah angklung salendro dan pelog (dami-na-ti-la-da) menjadi angklung diatonis (dore-mi-fa-sol-la-si). Inovasi yang dilakukan Daeng Soetigna ini memungkinkan angklung memainkan berbagai jenis musik, mulai dari lagu-lagu tradisional, hingga modern. Muali dari menjadi pengiring melodi lagu-lagu tersebut hingga dikolaborasikan dengan alatalat musik barat seperti piano, gitar, dan lainlain.

Jenis angklung diatonis merupakan inovasi dari jenis angklung pendahulunya, yaitu: angklung Buncis, angklung Baduy, angklung Badeng, dan angklung Kanekes. Saat ini angklung menjadi salah satu materi ekstrakurikuler di sekolah-sekolah sebagai media pembelajaran musik sebagaimana ditetapkannya Surat Keputusan Menteri Pendidikan dan Kebudayaan tanggal 23 Agustus 1963, No. 082/1963 (Gunawan, 2017).

\section{Pembelajaran Angklung Sebagai Media} Pengembangan Kognitif

Telaah literatur pembelajaran angklung pada penelitian ini mendasarkan pada penelitian yang dilakukan oleh Dini Nurmalina Firsty dan Myrnawati C.H, Hapidin (2017) dengan judul "Peningkatan Pemahaman Konsep Bilangan Melalui Bermain Angklung" yang dipublish dalam Jurnal Ilmu Pendidikan Harmonia.

Tujuan dari penelitian Fristy dan Hapidin adalah untuk mendeskripsikan proses dan hasil dari kegiatan bermain angklung untuk meningkatkan pemahaman konsep anak usia dini dan untuk meningkatkan pemahaman konsep bilangan pada anak di PAUD di Jakarta 2017. Responden dalam penelitian ini adalah 18 anak-anak dari kelompok B PAUD Alfani tahun 2017. Metode penelitian yang digunakan adalah penelitian tindakan model spiral Kemmis \& Taggart yang terdiri dari: 1) 
perencanaan, 2) tindakan dan observasi, 3) refleksi. Instrumen yang digunakan adalah catatan lapangan, wawancara, dan dokumentasi. Skor pemahaman data tentang konsep bilangan pada anak-anak dianalisis baik secara kuantitatif maupun kualitatif.

Hasil analisis data menunjukkan bahwa konsep pembelajaran pada peserta didik meningkat dari pra-siklus, siklus pertama, dan siklus kedua. Mengacu pada pengamatan tindakan yang telah dilakukan pada data yang diberikan pada tingkat kejadian 40,09\%, dan pada siklus pertama menjadi $59,41 \%$ dan kemudian meningkat pada siklus kedua sebesar $85,61 \%$. Hasil akhir dari penelitian ini 1) kegiatan bermain angklung dapat meningkatkan pemahaman konsep dalam Bahasa Indonesia PAUD anak kelompok B Alfani tahun 2017, 2) skor pemahaman konsep pada kelompok anak B PAUD Alfani tahun 2017 meningkat dari siklus awal ke siklus pertama dan siklus pertama ke siklus kedua.

\section{Proses Bermain Angklung Dalam Meningkatkan Pemahaman Konsep}

Proses bermain angklung di kelompok B PAUD Alfani dilakukan dalam 2 siklus. Peneliti dan kolabolator membuat perencanaan kegiatan bersama dan meyepakati, siklus I dilaksanakan sebanyak 12 kali pertemuan. Peneliti dan kolabolator menentukan jadwal pelaksanaan kegiatan dan menyepakati perencanaan bentuk RPPM (Rencana Pelaksanaan Pembelajaran Mingguan) dan RPPH (Perencanaan Pelaksanaan Pembelajaran Harian). Pada setiap pertemuan peserta didik akan memainkan lagu yang berbeda-beda. Ini dilakukan agar anak tidak bosan dan jenuh saat bermain angklung.

Pada pertemuan pertama peserta didik diperkenalkan terlebih dahulu tentang angklung. meliputi bentuk dan bagaimana cara memainkannya. Selanjutnya peserta didik juga diperkenalkan dengan not angka sebagai sarana memainkan lagu. Pada pertemuan ke 2 peserta didik memainkan lagu "Cicak-cicak di Dinding" dengan melihat isyarat jari guru. Pertemuan ke 3 anak bermain lagu "Balonku" dengan melihat isyarat jari guru. Pada pertemuan ke 4 anak bermain lagu "Kasih Ibu" dengan melihat isyarat jari guru.
Pertemuan ke 5 peserta didik bermain lagu "Dua Mata Saya" dengan melihat isyarat jari guru. Pada pertemuan ke 6 peserta didik bermain angklung lagu "Lihat Kebunku" dengan melihat isyarat jari guru. Pada pertemuan ke 7 peserta didik bermain angklung lagu "Pelangi-pelangi" dengan melihat isyarat jari guru.

Pada pertemuan ke 8 peserta didik bemain angklung lagu "Satu-satu Aku Sayang Ibu" dengan melihat isyarat jari guru. Pada pertemuan ke 9 peserta didik bermain angklung lagu "Kasih Ibu" dengan melihat isyarat jari guru. Pada pertemuan ke 10 peserta didik bermain angklung lagu "Topi Saya Bundar" dengan melihat isyarat jari guru. Pada pertemuan 11 peserta didik bermain angklung lagu "Topi Saya Bundar" dengan melihat isyarat jari guru. Pada pertemuan 12 peserta didik bermain angklung lagu "Ibu Kita Kartini". Pada pertemuan terakhir guru dan peneliti menentukan siapa peserta didik yang skornya paling banyak dan siapa peserta didik yang skornya paling sedikit.

Pada siklus II, berdasarkan hasil diskusi antara peneliti dan kolabolator dilaksanakan 12 kali pertemuan dengan menggunakan kegiatan bermain angklung. Pelaksanaannya hampir sama dengan beberapa perbedaan dibandingkan dengan siklus I karena disesuaikan dengan hasil refleksi pada kegiatan siklus I. Perbedaan tersebut antara lain: pada siklus I Guru lebih banyak berperan aktif dalam pembelajaran. Sedangkan pada siklus II peserta didik didorong berpartisipasi lebih aktif dan guru bertindak hanya sebagai fasilitator dan motivator.

Pada siklus I peserta didik diminta untuk bermain angklung bersama-sama, sedangkan pada siklus II mereka dibagi menjadi 2 kelompok yang terdiri dari 8 orang. Pada siklus I guru memberikan instruksi pada peserta didik dengan isyarat jari, namun pada siklus II guru hanya akan menunjukan angka pada not di papan tulis sebagai pengganti instruksi jari.

Pada siklus I, perhatian guru terhadap peserta didik cenderung umum. Dalam artian perseta didik yang aktif dan tidak diperlakukan sama, sedangkan pada siklus II guru akan memberikan perhatian pada peserta didik 
yang kurang aktif. Pada siklus I Peserta didik lebih fokus bermain angklung daripada mengembangkan pemahaman konsep bilangan sedangkan pada siklus II Peserta didik bermain sambil mengembangkan pemahaman konsep bilangan.

Hasil Pengamatan Bermain Angklung dalam Meningkatkan Pemahaman Konsep Bilangan

Hasil penelitian pada kelompok B PAUD Alfani dengan responden 18 orang peserta didik menunjukan peningkatan pada pemahaman konsep bilangan pada peserta didik. Berdasarkan analisis pada prasiklus, rata-rata skor peserta didik sebesar 40,09\% Skor tersebut meningkat pada siklus I sebesar $59,41 \%$ dan meningkat lagi pada siklus II sebesar $85,61 \%$.

Berdasarakan paparan data tersebut, maka peningkatan pemahaman konsep bilangan telah mencapai hasil yang disepakati oleh peneliti dan kolabolator, serta menunjukan hasil bahwa bermain angklung dapat meningkatkan pemahaman konsep bilangan pada peserta didik kelompok B PAUD Alfani tahun 2017.

Meningkatknya pemahaman konsep bilangan pada siklus II pada peserta didik sudah memenuhi kriteria keberhasilan sesuai kesepakatan peneliti dan kolabolator. Hal ini menunjukan kegiatan bermain angklung dapat meningkatkan pemahaman kosep bilangan peserta didik. Analisis data kualitatif dibuat berdasarkan hasil catatan lapangan, wawancara, dan dokumentasi dengan tahapan reduksi data, display data, dan penarikan kesimpulan. Berikut ini pemaparan data kualitatif dari indikator-indikator bermasalah pada penelitian ini dengan tindakan bermain angklung dalam meningkatkan pemahaman konsep bilangan peserta didik kelompok B PAUD Alfani tahun 2017.

Berdasarkan hasil pengamatan peneliti dan kolabolator maka penelitian tersebut mancapai kesimpulan bahwa penerapan kegiatan bermain musik angklung dapat meningkatkan pemahaman konsep bilangan pada peserta didik kelompok B PAUD Alfani Bogor tahun 2017. Indikator yang digunakan, yaitu: mencocokan jumlah benda dengan lambang bilangan pada peserta didik mengalami kemajuan dari pra siklus ke siklus
I dan siklus II. Adapun hal yang terlihat dari, pertama, peserta didik mencocokan jumlah benda dengan lambang bilangan bersamasama dan dibantu oleh guru, kedua, peserta didik mencocokan jumlah benda dengan lambang bilangan bersama-sama tanpa dibantu oleh guru, ketiga, peserta didik mecocokan jumlah benda dengan lambang bilangan dalam lembar kerja yang diberikan guru.

\section{Pembelajaran Gamolan Sebagai Media Pengembangan Motorik}

Telaah literatur pembelajaran gamolan pada penelitian ini mendasarkan pada penelitian yang dilakukan oleh Karin Ariska yang berjudul "Penggunaan Gamolan sebagai Pengembangan Aspek Motorik Kasar Anak Usia Dini di Raudhatul Athfal At-Tamam Bandar Lampung. Penelitian ini merupakan penelitian S1 yang dilaksanakan pada tahun 2017-2018.

Penelitian ini bertujuan untuk mengetahui bagaimana alat musik gamolan bambu dikaitkan dan digunakan oleh guru di Raudhatul Athfal At-Tamam sebagai media mengingkatkan kemampuan motorik kasar peserta didiknya. Hasil penelitian terhadap pembelajaran gamolan bambu di Raudhatul Athfal At-Tamam ini diharapkan dapat menjadi salah satu media alternatif bagi guru dan Taman Kanak-Kanak atau Raudhatul Athfal dalam mengembangkan kemampuan motorik kasar anak usia dini yang dikaitkan dengan aspek perkembangan musik.

Pengembangan motorik kasar di Raudhatul Athfal At-Tamam bertujuan untuk meningkatkan kemampuan mengelola, mengontrol gerakan tubuh dan koordinasi, serta meningkatkan keterampilan tubuh dan cara hidup sehat, sehingga dapat menunjang pertumbuhan jasmani yang sehat, kuat dan terampil. Sesuai dengan tujuan pengembangan jasmani tersebut, peserta didik didik dilatih gerakan-gerakan dasar yang akan membantu perkembangan motoriknya kelak.

Salah satu tujuan penerapan kegiatan Gamolan di Raudhatul Athfal At-Tamam adalah untuk meningkatkan kemampuan motorik kasar, yakni mematangkan kordinasi mata dan tangan, serta kordinasi dua tangan (kanan-kiri). Sebab bermain gamolan membutuhkan dua kemampuan dasar tersebut 
agar dapat memainkan lagu dan agar dapat bermain bersama-sama secara berkelompok. Oleh sebab itu, ibu Resti sangat fokus pada dua kemampuan tersebut ketika peserta didikpeserta didik berkegiatan dengan alat musik Gamolan. Berikut disajikan table indikator yang hendak dicapai oleh Raudhatul Athfal At-Tamam melalui pembelajaran gamolan.

Tabel 1. Indikator Dan Sub-Indikator Pembelajaran Gamolan Untuk Peserta didik Usia Dini Di Raudhatul Athfal At Tamam

\begin{tabular}{|c|c|c|}
\hline No. & Indikator & Sub-Indikator \\
\hline 1. & $\begin{array}{l}\text { Koordinasi antara tangan } \\
\text { dan mata }\end{array}$ & \begin{tabular}{lr} 
& Peserta didik \\
mampu memukul \\
$1 \quad$ (satu) bilah \\
gamolan secara \\
tepat sesuai \\
instruksi guru. \\
\multicolumn{4}{c}{ Peserta didik } \\
mampu memukul \\
bilah gamolan \\
secara berurutan \\
dari nada rendah \\
ke tinggi.
\end{tabular} \\
\hline 2. & $\begin{array}{l}\text { Terampil menggunakan } \\
\text { tangan kanan dan kiri } \\
\text { (Koordinasi tangan kanan } \\
\text { \& kiri) }\end{array}$ & $\begin{array}{l}\text { - Peserta didik } \\
\text { mampu memukul } \\
\text { bilah gamolan } \\
\text { dengan } 1 \text { tangan } \\
\text { (tangan kanan). } \\
\text { - Peserta didik } \\
\text { mampu memukul } \\
\text { bilah gamolan } \\
\text { dengan tangan } \\
\text { kanan dan kiri } \\
\text { secara bersamaan }\end{array}$ \\
\hline
\end{tabular}

Berdasarkan hasil analisis dan pembahasan yang sudah penulis jabarkan sebelumnya maka penulis menyimpulkan bahwa penggunaan media gamolan untuk mengembangkan motorik kasar peserta didik usia dini di Raudhatul Athfal At-Tamam Bandar Lampung sudah berkembang secara maksimal dikarenakan guru selalu menyusun perencanaan terlebih dahulu seperti, menyiapkan materi yang akan disampaikan, menyusun tahapan pembelajaran gamolan, dan menentukan indikator capaian pembelajaran, lalu pelaksanaan pembelajaran gamolan dan yang terakhir mengevaluasi pembelajaran.

Berdasarkan hasil wawancara, observasi dan dokumentasi yang penulis lakukan pada kelompok B usia 5-6 tahun yang berjumlah 15 peserta didik, guru berhasil mengembangkan motorik kasar peserta didiknya dengan menggunakan dua indikator, yakni kordinasi mata dan tangan, serta kordinasi tangan kanan dan kiri. Oleh sebab itu, penggunaan alat musik gamolan dapat menjadi salah satu media alternatif yang baik guna meningkatkan aspek motorik peserta didik usia dini.

\section{Metode penggunaan Gamolan untuk Meningkatkan aspek Motorik}

Sebagaimana dijelaskan pada tahap perencanaan, pelaksaan awal pembelajaran gamolan ini dibagi dalam 4 (empat) tahap, yaitu : a) Pengenalan, b) pengenalan posisi bermain, c) berlatih memegang pemukul gamolan, d) berlatih memukul gamolan. Berikut dipaparkan hasil pengamatan pelaksaan pembelajaran tersebut:

Pada tahap awal ini guru memperkenalkan secara umum tentang alat musik gamolan, seperti bahan pembuatnya, asal instrumen. Guru terlihat berupaya juga mengkaitkannya dengan materi pembelajaran lain seperti tentang tumbuhan bambu yang merupakan bahan baku pembuatan gamolan. Selain itu pula guru menyisipkan informasi tentang asal alat musik ini. Guru menjelaskan bahwa alat musik ini milik suku Lampung, yaitu suku asli provinsi Lampung.

Tahap berikutnya adalah pengenalan Posisi Bermain. Pada tahap ini guru posisi bermain gamolan yang baik, yakni dengan duduk bersila dan meletakan gamolan di depan peserta didik. Guru memaparkan jarak antara pemain dengan gamolan menyesuaikan dengan postur tubuh masing-masing peserta didik. Di sini guru tampak memperhatikan satu-persatu peserta didik agar mendapatkan posisi yang baik bagi masing-masingnya. Sementara para peserta didik duduk bersila dan diminta menghafalkan masing-masing sejauh mana gamolan harus diletakkan di depan tubuh masing-masing peserta didik.

Berlatih Memegang Pemukul, Pada tahap ini guru menunjukan cara memegang pemukul gamolan yang baik agar peserta didik dapat menggunakan pemukul dengan maksimal. Sebelum diberikan instruksi, para peserta didik tampak memegang pemukul secara tidak beraturan. Dan cenderung memegang dengan mengepal dengan seluruh tangan. Kemudian guru mendemostrasikan cara yang baik dalam memegang pemukul. Setelah 
mendemostrasikan guru memastikan tiap-tiap peserta didik mengikuti instruksi yang telah diberikan. Namun ibu Rasty menjelaskan, bahwa tidak semua peserta didik mengikuti cara yang ia demostrasikan sebab nantinya akan kembali ke masing-masing peserta didiknya, posisi memegang seperti apa yang dirasa paling nyaman. Namun tetap ia menjunjukan cara memegang yang paling ideal.

Pada tahap ini guru memberikan waktu yang cukup kepada peserta didik untuk mengingat cara memegang pemukul. Misalnya setelah peserta didik dapat memegang dengan baik, lalu guru meminta meletakan pemukulnya di lantai. Lalu guru meminta peserta didik memegangnya kembali dengan posisi yang benar. Latihan ini dilakukan berulang-ulang agar peserta didik dapat menghafal serta terbiasa memegang pemukul gamolan.

Setelah peserta didik dapat memegang pemukul gamolan dengan baik, tahap selanjutnya dilakukan guru ialah memberikan arahan kegiatan selanjutnya, yaitu latihan memukul bilah-bilah gamolan secara beraturan. Untuk membiasakan memukul bilah dengan beraturan dan tepat sesuai instruksi guru, peserta didik diminta memulai dengan memukul tiga bilah secara berurutan. Urutan pertama pada latihan ini adalah memukul 3 bilah pertama dari kiri, yakni : do, $r e$, dan $m i$ secara bersama-sama. Latihan ini dimulai dengan tempo yang lambat dan dicoba berulang-ulang dengan instruksi guru.

Tujuannya adalah agar peserta didik terbiasa memukul bilah yang dimaksud dengan tepat. Percobaan awal ini tidak semua peserta didik dapat mengikuti dengan baik. Sebagian besar mereka memukul bilah dengan tidak tepat. Namun setelah percobaan berulang-ulang, nada $d o$, re, dan $m i$ dapat dimainkan bersamasama secara teratur. Pada tahap ini juga guru memberikan perhatian pada tiap-tiap peserta didik dan berupaya untuk menyelesaikan hambatan yang dimiliki masing-masing peserta didik yang masing kesulitan memukul dengan tepat. Yang umum terjadi peserta didik tidak memposisikan pemukul berdekatan dengan bilah, sehingga ketika memukul, peserta didik tidak mempersiapan dengan baik bilah mana yang hendak dipukul. Akibatnya pukulan meleset pada bilah-bilah yang lain. Guru memberikan waktu yang relatif cukup bagi peserta didik untuk berlatih tahap ini, agar dapat dengan baik memasuki tahap latihan berikutnya.

Kemudian tahap selanjutnya upaya yang dilakukan guru ialah memberikan instruksi ke peserta didik untuk memukul bilah gamolan secara berurutan dari nada rendah ke tinggi, yakni : do, re, mi, sol, la, si, dan do. Pada tahap ini konsetrasi peserta didik dalam memukul gamolan ditingkatkan. Masih dengan tempo yang lambat. Guru mendemostrasikan bilah-bilah yang dipukul dan diikuti oleh peserta didik bersama-sama. Membutukan berulangkali percobaan hingga peserta didik dapat memukul bilah seperti yang diharapkan.

Setelah peserta didik mulai terbiasa memukul bilah-bilah gamolan dengan tepat, maka guru memulai tahap selanjutnya, yakni memulai berlatih kordinasi tangan kanan dan kiri. Guru mendemonstrasikan cara berlatih ini, yaitu dengan menempatkan tangan kiri pada bilah do dan tangan kanan pada bilah mi. Pola latihan ini guru meminta peserta didik memukul bersamaa kanan dan kiri lalu tangan kanan. Guru sambil terus menyanyikan pola latihan ini dengan instruksi bareng kanan bareng kanan, hingga peserta didik terbiasa dengan pukulan tersebut.

\section{Hasil Pengamatan Bermain Gamolan Meningkatkan Keterampilan Motorik}

Berdasarkan hasil obsevasi yang dilakukan di Raudhatul Athfal At-Tamam Bandar Lampung, dimana diakhir kegiatan setelah melakukan pelaksanaan pembelajaran guru melakukan evaluasi untuk mengulas kembali pembelajaran yang telah dilaksanakan peserta didik dimana tujuan nya agar peserta didik memahami dan mengingat kembali suatu kegiatan atau pembelajaran yang telah dilaksanakan peserta didik tadi.

Pada saat mengevaluasi pembelajaran yang telah dilakukan guru bertanya kesulitan yang di alami saat melakukan pembelajaran gamolan, guru kemudian mencontohkan kembali gerakan yang dianggap peserta didik sulit kemudian selanjutnya peserta didik mengikuti kembali gerakan tersebut, dengan begitu diharapkan peserta didik akan lebih memahami serta lebih mudah mengingatnya. 
Berdasarkan hasil observasi yang dilakukan penulis dari hasil data Penggunaan Media Gamolan untuk Mengembangkan Motorik Kasar Peserta didik Usia Dini di Raudhatul Athfal At-Tamam Bandar Lampung, berdasarkan hasil wawancara, observasi dan dokumentasi yang penulis lakukan pada siswa kelompok B usia 5-6 tahun yang berjumlah 15 anak, guru berhasil mengembangkan motorik kasar peserta didiknya dengan menggunakan dua indikator, yakni kordinasi mata dan tangan, serta kordinasi tangan kanan dan kiri. Tingkat keberhasilan ini mencapai $27 \%$ anak yang belum berkembang (BB), yang mulai berkembang (MB) 27\% dan berkembang sesuai harapan (BSH) 46\%. Oleh sebab itu, penggunaan alat musik gamolan dapat menjadi salah satu media alternatif yang baik guna meningkatkan aspek motorik anak usia dini.

\section{SIMPULAN}

Setelah memaparkan telaah literatur sebagai sample sebagaimana dijelaskan di atas, penelitian ini berkesimpulan bahwa alat musik tradisional seperti gamolan dan angklung juga dapat menjadi media yang baik guna meningkatkan aspek perkembangan peserta didik usia dini dilihat dari kesimpulan penelitian yang dibuat oleh masing-masing peneliti. Dengan metode dan proses yang tepat, penelitian Dini Nurmalina Firsty dan Myrnawati C.H, Hapidin (2017) dengan judul "Peningkatan Pemahaman Konsep Bilangan Melalui Bermain Angklung" Berdasarkan pada pengamatan tindakan yang telah dilakukan pada data yang diberikan pada tingkat kejadian $40,09 \%$, dan pada siklus pertama menjadi $59,41 \%$ dan kemudian meningkat pada siklus kedua sebesar $85,61 \%$. Itu Hasil dari penelitian ini adalah (1) kegiatan bermain angklung dapat meningkatkan pemahaman konsep dalam Bahasa Indonesia PAUD peserta didik kelompok B Alfani tahun 2017, (2) skor pemahaman konsep pada kelompok peserta didik B PAUD Alfani tahun 2017 meningkat dari siklus awal ke siklus pertama dan siklus pertama ke siklus kedua.

Sementara itu pada penelitian Ariska (2018) juga memberikan kesimpulan yang mendukung penelitian ini. Berdasarkan hasil wawancara, observasi dan dokumentasi yang penulis lakukan pada kelompok B usia 5-6 tahun yang berjumlah 15 peserta didik, guru berhasil mengembangkan motorik kasar peserta didiknya dengan menggunakan dua indikator, yakni kordinasi mata dan tangan, serta kordinasi tangan kanan dan kiri. Oleh sebab itu, penggunaan alat musik gamolan dapat menjadi salah satu media alternatif yang baik guna meningkatkan aspek motorik peserta didik usia dini.

Hasil dari telaah literatur menunjukan manfaat musik sebagai kegiatan yang efektif bagi pengembangan aspek motorik dan kognitif anak, serta mendukung pemanfaatan alat musik trasidional Indonesia sebagai media untuk mencapai tujuan tersebut. Untuk itu alat-alat musik tradisional Indonesia dapat menjadi ide bagi guru sebagai sarana pengembangan kecerdasaan peserta didik dalam pendidikan anak usia dini.

\section{DAFTAR PUSTAKA}

Ariska, K. (2018). Penggunaan Gamolan Sebagai Pengembangan Aspek Motorik Kasar Anak Usia Dini Di Raudhatul Athfal At-Tamam Bandar Lampung. Repository Uin Raden Intan Lampung.

Artan Ismihan \& Balat, G. U. (2003). Recognition Of Musical Instruments By Children Between 4 And 6 Years Of Age And Research Concerning The Natural Sounds They Associate With Those Instruments. Contemporary Issues In Early Childhood, 4 Number 3.

Asolihin. (2020). Mengenalkan Sejak Dini Alat Musik Tradisional Kepada Anak. Https://Paud-

Anakbermainbelajar.Blogspot.Co.Id/201.

Corrigall \& Schellenberg, G. (2015). The Child As Musician: A Handbook Of Musical Development. Oxford Scholarship Online.

Gunawan, E. (2017). Pelatihan Angklung Dalam Kegiatan Ekstrakurikuler Di Smp Negeri 5 Bandung. Universitas Pendidikan Indonesia., Repository.Upi.Ed.

Harrison, G. P. (2016). Rainstorm Activities For Early Childhood Music Lessons Inspired By Teachable Moments. National Association For Music Education., 30.

Hasyimkan. (2011). Pertunjukan Musik Gamolan Lampung. Kajian Bentuk Dan Fungsinya Di Tengah-Tengah Masyararakt Lampung. Tesis Pascasarjana Ugm Program Studi Kajian Seni Pertunjukan. 
Lwin, M. Dkk. (2005). How To Multiply Your Child's Intelligence. Cara Mengembangkan Berbagai Komponen Kecerdasan (Edisi Indonesia). In Indeks, Yogyakarta. Indeks.

Miendlarzewska \& Trost, W. (2014). How Musical Training Affect Cognitive Development: Rhythm, Reward And Other Modulating Variables. Frontiers In Neuroscience.

Musfiroh, T. (2008). Pengembangan Kecerdasan Majemuk. Modul Perkuliahan: Pendidikan Anak Usia Dini. Universitas Terbuka.

Nurmala, D. (2017). Peningkatan Pemahaman Konsep Bilangan Melalui Bermain Angklung. Jurnal Ilmu Pendidikan., Universitas Negeri Jakarta.

Rasyid, R. (2016). Panggung Mandala Untuk Pendidikan Seni: Survey Laporan Kaori Iwai Dalam The Contribution Of Arts Education For Children Live's. Jurnal Darul Ilmi, 152.

Rose, Colin \& Malcolm, J., N. (2002). Accelerated Learning For 21 Century Cara Belajar Cepat Abad 21. Penerbit Nuansa.

Roska, B. (2020). Pendidikan Angklung Untuk Pendidik Usia Dini. 12 April 2020. Http://Citizen6.Liputan6.Com/Read/325766/ Pendidikan-Angklung-Untuk-Pendidik-UsiaDini.

Supriadi, D. (2006). Model Pembelajaran Musik Angklung Sunda Kreasi Di Sanggar Saung Angklung Udjo Nglagena, Padasuka Bandung Jawa Barat. Harmonia Jurnal Pengetahuan Dan Pemikiran Seni.

Widintoro, H. (2020). Meneruskan Musik Tradisional Sejak Dini. Https://Hendricuswidiantoro.Wordpress.Co m/2014/12/07/Gamelan-Meneruskan-MusikTradisional-Sejak-Dini/.

Wisbey, A. (1980). Music As The Source Of Learning Mtp Press Limited• International Medical. Lancasfer $\bullet$ England.

Yampolsky, P. (1996). Gong And Vocal Music From Sumatra: Talempong, Didong, Kulintang, Sholawat Dulang. Smithsonian Institut. 